\title{
Tulevaisuus tehdään yhdessä
}

\author{
Eeva-Mari Miettinen
}

\section{TIIVISTELMÄ}

—ässä käytäntökuvauksessa kuvataan Making my future -projektia (Interreg Central Baltic 2019-2021) sosiaalipedagogisena käytännön työnä ja toimintana. Projektiin osallistui 17-25-vuotiaita nuoria aikuisia Virosta, Latviasta ja Suomesta ajankohtana, jolloin koronapandemia mullisti yhteiskuntien toimintaa ja haastoi kansainvälistä yhteistyötä. Projektissa tavoitteena oli vahvistaa toimintaan osallistuvien nuorten toimijuutta ja osallisuutta sekä positiivista tulevaisuusorientaatiota kehkeytyvän aikuisuuden ikävaiheessa, jolloin tehdään koko elämän kannalta tärkeitä päätöksiä koulutuksesta ja elämäntavasta. Sosiaalipedagoginen ajattelu ja teoria ovat toimineet perustana projektin tavoitteille ja työotteelle. Kuvauksen keskiössä on positiivinen tulevaisuusorientaatio sekä projektin intensiiviviikoilla (2020-2021) hyödynnetyt luovat ja toiminnalliset menetelmät, jotka mahdollistavat ja kannustavat osallistumiseen ja osallisuuteen omassa elämässä ja lähiympäristössä sekä tukevat yhteiskuntaan kiinnittymistä. Projektissa nuoret ovat toimineet ja oppineet yhdessä, toisiltaan ja toisistaan osana monikulttuurisia ryhmiä. Lähtökohtana toiminnassa on ollut kokemuksellinen oppiminen ja yhteisössä kasvaminen siten, että nuorille itselleen mahdollistuisi runsaasti vaikuttamisen mahdollisuuksia niin projektin puitteissa kuin omassa elämässään.

Asiasanat: tulevaisuusorientaatio, osallisuus, nuoret, sosiaalipedagogiikka 


\section{ABSTRACT}

\section{MAKING THE FUTURE TOGETHER}

- This article describes Making my future (Interreg Central Baltic 2019-2021) project as social pedagogical work and action. The aim of "Mamyfu" has been enhancing participation and emphasizing the meaningfulness of positive future orientation in insecure state of life and societal conditions. The time of emerging adulthood (ages of 17 to 25 ) is a period when the future is shaping up by the choices the young make for their education, family and work life. "Mamyfu" has brought together 35 young and 10 professionals from Estonia, Latvia, and Finland. The project consisted mainly of three intensive weeks organized during 2020-2021 with pre- and postactivities where young people collaborated in multicultural groups and in their own communities. Social pedagogical theory and thinking has formed a base for the objectives and approaches of the project. During the project, photo voice, improvisation, drama and game-designing were the most important action and creativity-oriented methods used.

Keywords: participation, future orientation, young people, social pedagogy

\section{Johdanto}

M aking my future -projektissa tavoitteena on ollut vahvistaa toimintaan osallistuvien nuorten toimijuutta ja positiivista tulevaisuusorientaatiota. Projektissa kokeiltiin ja toteutettiin erilaisia luovia ja toiminnallisia menetelmiä, jotka mahdollistavat ja kannustavat osallistumiseen ja osallisuuteen omassa elämässä ja lähiympäristössä sekä tukevat yhteiskuntaan kiinnittymistä.

Projektin toteutusaikana koronapandemia on mullistanut maailmaa monin tavoin. Projektin tavoitteena on ollut nimensä mukaisesti omien tulevaisuuksien tekeminen, mutta haastava globaali pandemia on pakottanut myös reagoimaan ja sopeutumaan muuttuviin tilanteisiin proaktiivisen tulevaisuuksien tekemisen ohessa. Koronakriisi on toisaalta myös korostanut Making my future -projektin kaltaisen toiminnan tärkeyttä. Erityisesti nuoret aikuiset tarvitsevat tilaa ja mahdollisuuksia reflektoida omia elämänpolkujaan turvallisesti ja luottamuksellisesti. Lisäksi heidän tulee saada tukea toimijuutensa vahvistumiseen.

Nuoret aikuiset tarvitsevat toivoa ja taitoja ollakseen oman elämänsä polulla toimijoita, ei matkustajia. Globaalin kriisin mukanaan tuoman 
epävarmuuden, sosiaalisen etäisyyden ja liikkumisrajoitusten aikoina on keskeistä luoda yhteisyyttä, joka kantaa valtioiden rajojen yli. Kansainvälisellä projektilla on voitu tarjota nuorille pandemian aikana toivoa ja tukea tulevaisuudenkuvien rakentamiseen.

Tässä tekstissä kuvataan Making my future -projektia sosiaalipedagogisena käytännön työnä ja toimintana. Sosiaalipedagoginen ajattelu ja teoria ovat luoneet perustaa projektin tavoitteille ja työotteelle. Keskeisinä teoreettisina näkökulmina tässä kuvauksessa ovat tulevaisuusorientaatio sekä projektin intensiiviviikoilla hyödynnetyt luovat ja toiminnalliset menetelmät.

\section{Making my future -projekti}

Making my future -projekti (2019-2021) on Interreg Central Balticin rahoittama, ja sitä on johtanut Tampereen ammattikorkeakoulu. Projektin tavoitteena on ollut voimavaraistaa nuoria aikuisia löytämään omat mahdollisuutensa ja potentiaalinsa omissa elämissään ja yhteisöissään sekä auttaa huomaamaan, kuinka nuoret itse voivat vaikuttaa omiin lähiyhteisöihinsä toimimalla proaktiivisina tulevaisuuksien tekijöinä.

Projektiin kutsuttiin osallistumaan erilaisia haastavia elämäntilanteita kohdanneita, iältään 17-25-vuotiaita nuoria ja nuoria aikuisia. Projektissa toteutuneen toiminnan myötä pyrittiin vahvistamaan heidän positiivista tulevaisuusorientaatiotaan, itseluottamustaan ja yhdessä oppimista. Yhteistoiminta ja yhdessä oppiminen ovat olleet projektissa sekä keino että tavoite.

Projektiin osallistui nuoria aikuisia Virosta, Suomesta ja Latviasta. Viron osallistujat tulivat Peipsin alueen maaseudulta, jossa on havaittavissa vahvaa muuttoliikettä kaupunkeihin. Haja-asutusalueen nuoret ovat kohdanneet haasteita muun muassa paikallisyhteisöihin ja työelämään kiinnittymisessä. Latviasta projektipartnerina oli lastensuojelun asiakkaille tukea tarjoava Resilience Center. Järjestön toimintatapojen ydintä ovat luovat ja toiminnalliset menetelmät. Suomen osallistujat puolestaan tulivat Tampereen seudulta. Nuoret ovat eri toimijoiden kautta tavoitettuja turvapaikanhakijoita, jotka ovat tulleet alaikäisinä yksin Suomeen mutta täysi-ikäistyneet projektin aikana. Merkittävä osa kaikista projektin nuorista saa tai on saanut jälkihuollon tukea.

Making my Future -projektissa keskiöön nousi yhteistyö työntekijöiden ja osallistuvien nuorten kesken. Nuorille pyrittiin mahdollistamaan osallistumista ja osallisuutta siten, että he voisivat hyödyntää jatkossa ko- 
kemustaan ja vahvistaa omaa tulevaisuusorientaatiotaan. Intensiiviviikkojen ohjelmarunkoon jätettiinkin väljyyttä nuorten omalle ideoinnille. Yksi projektin perusajatuksista on ollut "We have a plan, and we have no plan.” Tällä tarkoitamme sitä, että nuorille luodaan tilaa ja mahdollisuuksia olla aktiivisesti tuottamassa ja luomassa toiminnan sisältöä sen sijaan, että ohjaajat suunnittelisivat ja ohjaisivat kaiken toiminnan.

Hankkeen keskeisenä toteutustapana ovat olleet Suomessa, Latviassa ja Virossa järjestettävät intensiiviviikot, joissa nuoret oppivat yhdessä, toisiltaan ja toisistaan. Osallistuessaan projektiin nuoret ovat saaneet kansainvälisiä kontakteja ja oppineet tekemään yhteistyötä monikulttuurisessa ympäristössä ja työryhmässä sekä kehittäneet monikulttuurisen kommunikaation taitoja.

Intensiiviviikoilla työskenneltiin luovin ja toiminnallisin menetelmin siten, että jokaisella intensiiviviikolla oli jokin pääteema ja keskeinen menetelmä. Osana jokaista intensiiviviikkoa nuoret toteuttivat jonkin pienen projektin lähiympäristössä. Tavoitteena oli tunnustella näkyväksi tulemista sekä julkiseen tekemiseen usein vähintäänkin aluksi liittyvää epämukavuutta.

Lähiympäristöön sijoittuvat projektit pyrittiin toteuttamaan nuorilähtöisesti ja nuorijohtoisesti työntekijöiden toimiessa fasilitaattorin roolissa. Nuorten toimijuuden asettaminen keskiöön on haastanut projektin ammattilaisia uudelleenorientoitumaan omiin työtapoihinsa ja päästämään irti vahvasta ohjaajuudesta sekä siirtymään ja kiinnittymään rinnallakulkijan rooliin ja vahvemmin sosiaalipedagogiseen työotteeseen.

\section{Sosiaalipedagogiikka lähtökohtana nuorten aikuisten tulevaisuustyöskentelyssä}

Making my future -projektin toiminta on luonteeltaan sosiaalipedagogista. Projektin toteutusta ja toimintaa on pyritty tietoisesti kehittämään sosiaalipedagogisen ajattelun ja teorian pohjalta, vaikka hankehakemuksessa sosiaalipedagogiikan käsitettä ei mainittu.

Sosiaalipedagogiikassa kiinnostuksen kohteena on ihmisen kasvu yhteisöjen ja yhteiskunnan jäseneksi ja jäsenenä, sekä kasvatustoiminta, jolla sosiaalista kasvua tuetaan. Kasvatuksellisella työotteella pyritään ehkäisemään ja lievittämään ongelmia vaikuttamalla sekä ihmisten omien voimavarojen vahvistumiseen että ympäröiviin olosuhteisiin. Historiallisesti sosiaalipedagoginen toiminta on syntynyt erityisesti lasten ja nuorten parissa tehtävän kasvatustyön kentällä. (Nivala \& Ryynänen 2017, 75-78.) 
Sosiaalipedagogiikan tutkimusperinteessä erottuu kaksi kehityslinjaa. Yhdessä korostuu pedagogisen avun tarjoaminen ihmisten erityisiin sosiaalisen toimintakyvyn ja integraation ongelmiin ja toisessa yhteiskunnan jäsenyyteen ja kansalaisuuteen kasvamisen tukeminen. (Hämäläinen 2007.) Kehityslinjat kietoutuvat käytännössä yhteen, ja tässä projektissa kiinnostavaa ja tärkeää onkin ollut juuri se, että vaikka hankesuunnitelman mukaisesti toimintaa on tarjottu vaikeissa elämäntilanteissa oleville nuorille, on jokainen pyritty projektin toiminnassa kohtaamaan kuin kuka tahansa nuori, joka on mukana jäsentämässä omaa suhdettaan erilaisiin yhteisöihin ja yhteiskuntiin. Yhden intensiiviviikon loppukeskustelussa eräs nuori kiittikin ohjaajia juuri siitä, että hänet nähtiin ensimmäistä kertaa omana itsenään eikä taustansa kautta: "Thank you for seeing me."

Sosiaalipedagogisessa toiminnassa merkittävää on kasvavien (nuorten) ja kasvattajien (projektityöntekijöiden) välisen pedagogisen suhteen rakentaminen ja toisaalta yhteisöjen vahvistaminen kasvun ympäristöinä. Yhteisöjen ja yhteisöllisyyden vahvistamisella tarkoitetaan erilaisia toimia, joilla tuetaan yhteen tulemista ja yhdessä toimimista sekä pyritään mahdollistamaan ja edistämään johonkin kuulumisen ja osallisuuden kokemuksia. Keskeistä on erityisesti avoimen vuorovaikutuksen ja tavoitteellisen yhteistoiminnan tukeminen ja siten mahdollisuuksien luominen yhteenkuuluvuuden tunteiden vahvistumiselle. (Nivala \& Ryynänen 2017, 76, 79.)

Making my future -projektissa osallisuus on ymmärretty ihmisen ja yhteisön välisenä suhteena, joka Nivalan ja Ryynäsen $(2019,138)$ mukaan toteutuu, kun ihminen on osa, toimii osana ja kokee olevansa osa yhteisöä. Projektisuunnitelman mukaisena tavoitteena on ollut osallisuuden edistäminen erityisesti vaikuttamisen prosesseissa. Projektin toimintaa on kehitetty yhdessä osallistujien kanssa, ja kokonaisuudessaan toiminnan tavoitteena on ollut osallistujien vaikuttamismahdollisuuksien vahvistaminen myös projektitoiminnan ulkopuolella (ks. Isola ym. 2017). Vaikuttamisosallisuutta on tuettu vahvistamalla osallistujien rohkeutta ja valmiuksia vuorovaikutukseen ja yhteistoimintaan sekä edistämällä kuulumisen kokemusta toiminnan kautta. Osallisuuden kokemuksen vahvistamisella on pyritty luomaan valmiuksia myös lähiyhteisöihin suuntautuvaan vaikuttamisosallisuuteen.

Making my future -projektissa on pyritty mahdollistamaan yhteisöön kuulumista niin maakohtaisissa ryhmissä kuin kansainvälisessä yhteisössä. Intensiiviviikkojen väliin jäi koronapandemiasta johtuen pitkiä tau- 
koja, joiden aikana järjestettiin paikallista toimintaa, online-työpajoja ja vaihdettiin kuulumisia. Nuorten haluttiin tietävän ja tuntevan, että heistä välitetään ja he ovat merkityksellisiä. Intensiiviviikoilla kiinnitettiin erityistä huomiota yhteisön rakentamiseen ja osallistujien välisten suhteiden tukemiseen. Viimeisen intensiiviviikon päätteeksi eräs nuori kuvasi, miten tärkeää oli ainaisen yksin kotona olemisen sijaan saada olla viikko osana välittävää yhteisöä. Kiinnittyminen kansainväliseen ryhmään on tukenut kyseistä nuorta myös rakentamaan omaa identiteettiään osaavana ja pystyvänä haastavasta elämäntilanteesta huolimatta.

Pedagogisen suhteen rakentaminen on ollut projektissa kiinnostavaa, innostavaa ja kasvattajia haastavaa. Fasilitaattorin rooliin asettuminen nuorilähtöisen toiminnan mahdollistamiseksi ei saa estää luottamukseen ja yhdenvertaisuuteen perustuvan suhteen rakentumista, vaan kasvattaja tukee rinnalla kulkijana tietoisesti nuoren inhimillistä kasvua ja herkistyy nuoren yksilökohtaisille tarpeille. Pedagogisen suhteen luominen ei onnistu manipuloimalla vaan vaatii nuoren oman tahdon heräämistä, halukkuutta työstää ja jäsentää omia tulevaisuudensuunnitelmia sekä halua ponnistella niiden saavuttamiseksi (Nivala \& Ryynänen 2019, 116).

\section{Kehkeytyvä aikuisuus}

Projektissa toimittiin nuorten aikuisten kanssa. Kehkeytyvän aikuisuuden ikävaiheessa tulevaisuuteen suuntautuminen on erityisen tärkeää, sillä silloin tehdään koko elämän kannalta tärkeitä päätöksiä koulutuksesta, työurasta ja elämäntavasta. Nuorten tulevaisuusorientaatio ja valinnat tavoitteiden saavuttamiseksi ovat sidoksissa yksilöllisen kehityksen lisäksi sosiaaliseen, yhteiskunnalliseen, kulttuuriseen ja ekologiseen kontekstiin. (Pölkki, Hämäläinen \& Vornanen 2018, 161.) 2020-luvun nuorta aikuisuutta sävyttävät vahvasti koronaan liittyvät vaikutukset.

Myöhäisistä teinivuosista noin 25-vuotiaaksi saakka nuori tutkii omia mahdollisuuksiaan koulutuksen, rakkauden, työn ja maailmankatsomuksen suhteen ja alkaa vasta vähitellen tehdä pysyviä valintoja. Ajanjaksoa voisikin kuvailla suurten toiveiden ja unelmien ajaksi. Toisaalta se on myös huolen ja epävarmuuden aikaa, eikä monilla ole aavistustakaan siitä, mihin tutkailut johtavat. Kehkeytyvälle aikuisuudelle on tunnusomaista erilaisten mahdollisten elämän suuntien etsintä. (Arnett 2000, 469; 2004, 3.)

Kehkeytyvä aikuisuus on länsimaissa heikosti normatiivinen. Se on monimutkainen ja muuttuva jakso, jonka sisältö eri yksilöillä on varsin 
heterogeeninen. Ympäristön asettamat rajat vaihtelevat suuresti, ja yksilöiden mahdollisuudet erilaisiin kokeiluihin ja etsintöihin ovat monin paikoin erilaiset. Myös erot persoonallisuudessa vaikuttavat aikuistumiseen suuresti. (Arnett 2000, 477-479.)

Zarrett ja Eccles $(2006,15)$ määrittävät muotoutuvaan aikuisuuteen liittyvien haasteiden onnistuneen hoitamisen vaativan psykososiaalista ja kognitiivista pääomaa sekä mahdollisuutta tutkailla elämän haasteita. Lisäksi nuori tarvitsee saavutettavissa olevaa ja riittävää sosiaalista tukea. Making my future -projektissa on pyritty luomaan nuorille paikka ja yhteisö, jossa pohtia omia elämänmahdollisuuksiaan tässä ajassa niin, että heille tarjoutuu niin vertaistukea kuin projektityöntekijöiden tukea - peräti kansainvälisessä kontekstissa.

Projektissa mukana olleet nuoret ovat saattaneet jäädä elämänsä varrella vaille tarvitsemaansa tukea. Aikuisuuden kynnyksellä riittävä sosiaalinen tuki on tarpeen ja yhteiskunnallisestikin tärkeää. Tähän aikuistumisen tukemiseen on viime aikoina reagoitu Suomessa lainsäätäjän toimesta. Lastensuojelulain $(417 / 2007,75 \S)$ ja kotoutumislain (1386/2010, 27§) mukaisen jälkihuollon ikärajaa nostettiin aiemmasta 21 ikävuodesta 25 ikävuoteen vuoden 2020 alusta, mikä mahdollistaa monipuolisemman ja vahvemman tuen nuoren aikuisuuden ikävaiheessa. Projektin osallistujina on ollut juuri jälkihuollon asiakkaita tai entisiä lastensuojelun asiakkaita.

\section{Positiivisen tulevaisuusorientaation rakentaminen}

Sosiaalipedagogiikassa korostuva yhteisöllisyys ja yhteiskunnallisen osallisuuden tukeminen vahvistavat nuorten yksilöllisiä tavoitteiden asetteluja ja voimavaroja (Pölkki, Hämäläinen \& Vornanen 2018, 193). Making my future -projektissa näihin sosiaalipedagogisiin kasvatuksellisiin tavoitteisiin on tartuttu tulevaisuusorientaation tarkastelun ja tukemisen kautta yhdessä nuorten kanssa.

Ajatus nuorten positiivisen tulevaisuusorientaation pedagogisesta rakentamisesta sopii luontevasti sosiaalipedagogiseen kehykseen, jossa yhteiskunta- ja kasvatustieteellisiä teorioita yhdistävällä pedagogisella toiminnalla edistetään ja tuetaan nuorten osallistumista ja osallisuutta. Nuorten kanssa työskennellessä on olennaista ottaa huomioon tulevaisuusorientaatio ja tukea nuorten omaa selviytymistä ja uskoa tulevaisuuteen, sillä osalle nuorista oman tulevaisuusperspektiivin rakentaminen on hyvin vaikeaa. Osa nuorista voi jäädä vuosiksi etsimään paikkaansa 
yhteiskunnassa vailla tulevaisuuden suunnitelmia. (Pölkki, Hämäläinen \& Vornanen 2018, 162-179.)

Kun tarkastellaan nuorten suhdetta tulevaisuuteen, voidaan Pölkin, Hämäläisen ja Vornasen $(2018,164)$ mukaan puhua tulevaisuudenkuvista, tulevaisuuskuvista, tulevaisuusperspektiivistä tai tulevaisuusorientaatiosta. Tulevaisuusorientaation määrittelyssä korostuvat yksilölliset tulevaisuutta koskevat ajatukset, suunnitelmat, motivaatio, toiveet ja tunteet. (Trommsdorff 1983; Nurmi 1991, Pölkin, Hämäläisen \& Vornasen 2018, 163 mukaan.)

Positiivisella tulevaisuusorientaatiolla tarkoitetaan valoisaa ja luottavaista tulevaisuudenodotusta ja sen tiedostamista, että voi itse vaikuttaa sekä omaan elämänkulkuun että lähipiiriin ja yhteiskuntaan. Tämä on jotain, johon nuoren on kasvettava ja jota itse kunkin on rakennettava. (Pölkki, Hämäläinen \& Vornanen 2018, 169-170.) Making my future -projektissa pyrittiin edistämään ja tukemaan juuri näiden tarvittavien kasvuprosessien syntymistä. Jokaisella aikakaudella on tältä osin omat haasteensa ja kipupisteensä, jotka koskevat sitä, minkälaisena kasvu- ja elinympäristönä yhteiskunta näyttäytyy (Pölkki, Hämäläinen \& Vornanen $2018,170)$.

Nuoret suuntautuvat eri tavoin menneisyyteen, nykyisyyteen ja tulevaisuuteen. Epävarmuuksien yhteiskunnassa nuorten tukeminen tulevaisuussuhteen rakentamisessa on vaativa kasvatuksellinen tehtäväkenttä. Sosiaalipedagogiikan kannalta tärkeää pitkittäistutkimustietoa haavoittuvassa elämäntilanteessa olevien nuorten tulevaisuusperspektiivistä on toistaiseksi tarjolla vähän. (Pölkki, Hämäläinen \& Vornanen 2018, 163, 166.)

Muun muassa Marjaana Kojon (2010) tutkimuksessa käy ilmi, että tulevaisuus näyttäytyy marginaalissa eläville nuorille epävarmana, avoimena ja vaikeasti ennakoitavana. Kojon (2010) mukaan marginaalissa olevien nuorten aikakäsitystä voi kutsua laajentuneeksi nykyisyydeksi. Tulevaisuuteen liittyvää huolta nuorille aiheuttavat niin globaalit ongelmat kuin suomalaisessa yhteiskunnassa ilmenevät haasteet esimerkiksi työllisyyteen liittyen.

Making my future -projektin kansainvälisyys luo vahvasti näkökulmaa kohti globaalia ajattelua tarjoamalla mahdollisuuksia ja keinoja positiivisen tulevaisuusorientaation vahvistamiseen. Projektin aikana on nuorten kanssa käsitellyissä teemoissa tartuttu ajankohtaisiin yhteiskunnallisiin ja globaaleihin haasteisiin ja pyritty edistämään valoisaa ja luottavaista 
tulevaisuusorientaatiota. Intensiiviviikoilla on edetty oman lähiympäristön tarkastelusta kohti globaalin pandemian ja ilmastonmuutoksen tarkastelua.

Haastavan elämäntilanteen aikana laajentuneessa nykyisyydessä eläminen voi olla keino hallita elämää ja ylläpitää omaa toimintakykyä (Pölkki, Hämäläinen \& Vornanen 2018, 167). Tulevaisuusorientaation tukemista ovat haastaneet koronan tuomat matkustusrajoitukset, jotka ovat vaikuttaneet suuresti hankkeen aikatauluihin. Intensiiviviikkojen väliset ajat ovat pidentyneet alkuperäisestä suunnitelmasta, ja suunnitelmia on jouduttu muuttamaan useita kertoja. Sitoutumisen tukemiseksi nuorille on järjestetty erilaisia online-työpajoja, paikallisia tapaamisia ja illanviettoja. Hankkeen keston pidentyminen on toisaalta myös mahdollistanut pidempikestoista vuorovaikutusta työntekijöiden ja osallistujien välillä, mikä on tukenut pedagogisen suhteen syvenemistä.

\section{Intensiiviviikoilla käytetyt luovat ja toiminnalliset menetelmät}

Sosiaalipedagogisessa työotteessa menetelmistä ei saa tulla itsetarkoituksellisia, vaan niiden tulee asettua työn välineiksi siten, että ne palvelevat sekä työn päämääriä että osallistujien tarpeita ja toiveita (Nivala \& Ryynänen 2017, 216). Making my future -projektin toiminnassa menetelmävalintoja on ohjannut luovuus, toiminnallisuus ja elämyksellisyys. Lähtökohtana on ollut kokemuksellinen oppiminen ja yhteisössä kasvaminen siten, että nuorilla itsellään on paljon vaikuttamisen mahdollisuuksia.

Intensiiviviikoilla käytetyt menetelmät on tarjottu nuorille välineiksi oman tulevaisuusorientaation ja toimijuuden rakentamiseen. Luovia ja toiminnallisia menetelmiä hyödyntämällä on pyritty mahdollistamaan ja helpottamaan osallistujien yhteistä toimintaa eli yhteistoiminnallisuutta. Ohjaajat eivät itse määrittele toimintaa ja tee ratkaisuja vaan pyrkivät edistämään yhteistyötä ja yhteistoiminnallista prosessia, jotka tuottavat osallistujille positiivisia kokemuksia. (Nivala \& Ryynänen 2019, 209.)

Ensimmäinen intensiiviviikko Making My Future järjestettiin Suomessa tammikuussa 2020. Nuoret tarkastelivat ja analysoivat omaa elinympäristöään ja lähiyhteisöjään sekä omaa rooliaan niissä pohtien haasteita, mahdollisuuksia, unelmia ja uhkia. Teeman käsittelyssä käytettiin Photo voice -menetelmää. Photo voice on Caroline Wangin ja Mary Ann Burrisin (1997) kehittämä menetelmä, jossa osallistujat tunnistavat, tallentavat ja muuttavat lähiympäristöään ja lähiyhteisöjään (tai muuttuvat itse suh- 
teessa niihin). Työskentelyssä tehtiin näkyväksi nuorten elämänpiiriä ja pysähdyttiin kuvien äärelle aikana, jolloin valokuvaaminen on jatkuvaa eikä kuviin välttämättä kiinnitetä sen suurempaa huomiota. Työskentelyssä annettiin ääni nuorille ja kuvalle itsessään. Osana työskentelyä harjoiteltiin myös kuvanmuokkausta ja yhdistettiin valokuviin akryylimaalausta. Viikon päätteeksi osallistujat rakensivat valokuvista ja tarinoista koostetun valokuvanäyttelyn, joka oli yleisölle avoin. Avajaisia vietettiin juhlallisin menoin ja näyttely oli esillä vielä pari viikkoa intensiiviviikon päätyttyä.

Toinen intensiiviviikko Future Post Corona toteutettiin Latviassa Liepajan kaupungissa korona-ajan lomassa elokuussa 2020. Viikon työmenetelminä olivat improvisaatio ja draama, joiden avulla tarkasteltiin epävarmuuden ja hetkessä elämisen teemoja sekä pohdittiin koronarajoitusten vaikutuksia nuorten elämässä. Improvisaatiota tarkasteltiin taitona ja rohkeutena olla oma itsensä muuttuvissa tilanteissa. Keskeiseksi kysymykseksi nousi: Kuka minä olen, kun maskit riisutaan? Vaikka emme tiedä, mitä tulevaisuus tuo tullessaan, voimme toimia, selvitä ja selviytyä, improvisoida tarvittaessa vaikka oman tulevaisuutemme uudelleen. Työskentelyssä ponnistettiin kohti pitkälle tähtäävää positiivista tulevaisuusorientaatiota harjoittelemalla läsnäoloa ja itsenämme olemista muuttuvissa tilanteissa. Työpajoja järjestettiin julkisissa tiloissa rannalla, aukioilla ja puistoissa. Viikon päätteeksi nuoret toteuttivat toritapahtuman, jossa oli koronateeman ympärille rakennettuja pelejä, tanssia, musiikkia ja kädentaitopajoja kaupunkilaisille.

Kolmannen intensiiviviikon teemana oli My Future, my Planet, ja menetelmänä olivat pelit ja pelillisyys. Viimeinen intensiiviviikko järjestettiin Virossa hybridiversiona siten, että suomalaiset nuoret osallistuivat Suomesta käsin. Intensiiviviikkoa jouduttiin koronarajoitusten takia siirtämään useita kertoja. Viikon aikana perehdyttiin kestävään kehitykseen ja ekologisiin näkökulmiin erilaisin pelillisin menetelmin, muun muassa roolipelien kautta. Intensiiviviikon projektina nuoret kehittivät eko-oppimispelejä perehtyen pelisuunnittelun prosessiin. Pelit esiteltiin Making my future -projektin loppuseminaarissa.

\section{Lopuksi}

Making my future -projektiin osallistuneet nuoret ovat kuvanneet intensiiviviikkoihin osallistumista merkitykselliseksi kokemukseksi. Viikot ovat tarjonneet mielekästä ja elämyksellistä sisältöä poikkeusolojen aikana. 
Kansainvälisessä ryhmässä toimiminen ja uudet kokemukset ovat lisänneet sisäistä voimaa ja joidenkin kohdalla vaikuttaneet myös identiteettiin siten, että maahanmuuttaja onkin muuttunut maailmankansalaiseksi.

Keskeisimpänä merkityksenä intensiiviviikoilta nousee esiin epämukavuusalueelle astuminen ja siellä pärjääminen yhdessä ryhmän kanssa. Lähiyhteisöissä toteutetut pienet projektit ja niiden kautta näkyväksi tuleminen ovat laajentaneet nuorten mukavuusaluetta ja sitä kautta heidän toimintavalmiuksiaan ja pystyvyyden kokemustaan. Nuoria on pyritty tukemaan kohti omia potentiaalejaan tarkastelemalla yhdessä tulevaisuuden mahdollisuuksia ja nykyhetken mahdollisuuksia. Vaikka tulevaisuuteen liittyy runsaasti epävarmuutta ja sitä on vaikea ennakoida, on projektiin osallistumisen kautta voinut saada voimavaroja nykyhetkessä pärjäämiseen sekä työkaluja positiivisen ja luottavaisen tulevaisuushorisontin rakentamiseen.

\section{LÄHTEET}

Arnett, J. 2000. Emerging Adulthood: The Theory of Development From the Late Teens Through the Twenties. American Psychologist 55 (5), 469-480.

Arnett, J. 2004. Emerging Adulthood: The Winding Road from Late Teens through the Twenties. Oxford: Oxford University.

Hämäläinen, J. 2007. Sosiaalipedagogiikan kaksi kehityslinjaa. Sosiaalipedagoginen aikakauskirja 8, 9-16.

Isola, A.-M., Kaartinen H., Leemann, L., Lääperi, R., Schneider, T., Valtari, S. \& KetoTokoi, A. 2017. Mitä osallisuus on? Osallisuuden viitekehystä rakentamassa. Helsinki: THL. Saatavissa https://www.julkari.fi/bitstream/handle/10024/135356/URN_ ISBN_978-952-302-917-0.pdf?sequence=1\&isAllowed=y (haettu 25.8.2021).

Kojo, M. 2010. Laajentunut nykyisyys: nuorten tulevaisuuteen suuntautuminen työn marginaalissa. Nuorisotutkimus 28 (2), 23-35. Saatavissa https://elektra.helsinki.fi/ oa/0780-0886/2010/2/laajentu.pdf (haettu 25.8.2021).

Kotoutumislaki 30.12.2010/1386. Saatavissa https://www.finlex.fi/fi/laki/ ajantasa/2010/20101386 (haettu 30.8.2021).

Lastensuojelulaki 13.4.2007/417. Saatavissa https://www.finlex.fi/fi/laki/ ajantasa/2007/20070417 (haettu 30.8.2021).

Nivala, E. \& Ryynänen, S. 2017. Sosiaalipedagoginen viitekehys nuorisoalan työssä. Teoksessa T. Hoikkala \& J. Kuivakangas (toim.) Kenen nuorisotyö. Yhteisöpedagogiikan kentät ja mahdollisuudet 2017. Helsinkin: Humanistisen ammattikorkeakoulun julkaisuja, 42. Nuorisotutkimusverkosto/Nuorisotutkimusseura, julkaisuja 196. Saatavissa https://www.humak.fi/wp-content/uploads/2017/12/hoikkalakuivakangas-kenen-nuorisotyo.pdf (haettu 25.8.2021). 
Nivala, E. \& Ryynänen, S. 2019. Sosiaalipedagogiikka. Kohti inhimillistä yhteiskuntaa. Helsinki: Gaudeamus.

Pölkki, P., Hämäläinen, J. \& Vornanen, R. 2018. Nuorten tulevaisuusorientaation tukeminen epävarmuuksien aikana. Teoksessa J. Lammintakainen \& S. Laulainen (toim.) Kohti vaikuttavaa päätöksentekoa ja johtamista hyvinvointipalveluissa. Kuopio: University of Eastern Finland. Saatavissa https://erepo.uef.fi/handle/123456789/20126 (haettu 25.8.2021).

Trommsdorff, G. 1983. Future Orientation and Socialization. International Journal of Psychology 18 (1-4), 381-406.

Wang, C. \& Burris, M. A. 1997. Photovoice: Concept, Methodology, and Use for Participatory Needs Assessment. Health Education and Behavior 24, 369-387.

Zarrett, N. \& Eccles, J. 2006. The passage to adulthood: challenges of late adolescence. New Directions for youth Development 111, 13-28. 